\title{
Article \\ Effects of Strip Roads in a Pine Tree Stand (Pinus sylvestris L.) on the Diameter Growth and Pith Eccentricity of Trees Growing along Them
}

\author{
Włodzimierz Stempski, Krzysztof Jabłoński (D) and Jakub Jakubowski *(D)
}

check for updates

Citation: Stempski, W.; Jabłoński, K.; Jakubowski, J. Effects of Strip Roads in a Pine Tree Stand (Pinus sylvestris L.) on the Diameter Growth and Pith Eccentricity of Trees Growing along Them. Forests 2021, 12, 1414. https:// doi.org/10.3390/f12101414

Academic Editor: Stefano Grigolato

Received: 16 September 2021

Accepted: 13 October 2021

Published: 16 October 2021

Publisher's Note: MDPI stays neutral with regard to jurisdictional claims in published maps and institutional affiliations.

Copyright: (c) 2021 by the authors. Licensee MDPI, Basel, Switzerland. This article is an open access article distributed under the terms and conditions of the Creative Commons Attribution (CC BY) license (https:// creativecommons.org/licenses/by/ $4.0 /)$.
Department of Forest Technology, Faculty of Forestry and Wood Technology, Poznań University of Life Sciences, Wojska Polskiego 71C, 60-625 Poznań, Poland; wlodzimierz.stempski@up.poznan.pl (W.S.); krzysztof.jablonski@up.poznan.pl (K.J.)

* Correspondence: jakub.jakubowski@up.poznan.pl

\begin{abstract}
Although skid roads are more and more commonly used in Poland, they are still quite often criticised due to a certain loss of wood volume and the impact on edge trees. In this context, the results of the research described in this article can be used as a substantive contribution to discussions about strip roads. Research was carried out in a 42-year-old pine tree stand (Pinus sylvestris L.) in the Notecka Forest, where thinning had been performed and 2.5 and $3.5 \mathrm{~m}$ wide strip roads had been cut 10 years before. The analysis comprised two five-year periods recording diameter growth and pith eccentricity in trees growing at the distance zones of 0-1 m (adjacent trees), 2-4 $\mathrm{m}$ and 8-10 $\mathrm{m}$ (the control) away from the strip roads. The differences in growth and eccentricity between the different distance zones as well as the frequency of pith eccentricity in the N-W, S-W, N-E and S-E directions were assessed, related to the distance from the strip road and the measurement height. The measurements of the analysed traits were conducted on wood discs cut from the centres of two-metre-long sections on sample trees (12 trees in each distance zone). The trees growing directly beside the strip roads were statistically significantly thicker than those growing 8-10 $\mathrm{m}$ away, and in the case of the trees beside the narrower strip roads, in the second 5-year period, they were also thicker than the trees from the 2-4 m distance zone. The effect of the wider strip roads in the first growth period was also significant for the trees growing $3 \mathrm{~m}$ away from the strip road (their growth in this period was significantly greater than that of trees in the control zone). The research into tree-pith eccentricity showed no differences due to relative distance from the strip road. Furthermore, no statistically significant relationship between the distance of trees from the strip road, measurement height and frequency of tree-pith eccentricity to the N-W and S-W were found.
\end{abstract}

Keywords: strip road; growth in diameter; tree pith eccentricity; Scots pine

\section{Introduction}

Sustainable forestry is multifunctional and thus supports the maintenance of the ecological, economic, social and cultural functions of forests for the present day and for the future [1-3]. The economic forest functions lie in wood production and harvesting. Although these functions, bringing the greatest revenues, are still very important for the forest economy, more and more often the value of other, non-productive forest services and products is stressed $[4,5]$.

The harvesting of wood is the activity that interferes most with the forest environment and arouses considerable interest among people [6]. Wood harvesting is one element of forest utilisation that in multifunctional forestry is not limited to taking specific material goods out of the forest, but also uses the forest space [7]. One use of forest space is the strip road, which is indispensable for machine movement, and when correctly designed, contributes to a reduction in damage to trees caused by wood harvesting operations [8-11]. Additionally, the need to protect the soil requires the machines to move on strip roads [12]. 
Inappropriate use of forest machines can lead to excessive soil compaction [13,14]. A high degree of soil compaction disrupts water relations in the soil, which consequently decreases the long-term productivity of the forest ecosystem [15]. In mechanised wood harvesting, strip roads make it possible to concentrate the logging waste left over after the processing operations, which limits the negative influence of machine travel on the soil [16-19].

Fully mechanised logging is widely used in many industrialised European countries, such as Sweden (approx. 98\%), Ireland (approx. 95\%) and Finland (approx. 91\%) [20]. Especially in the Baltic states, a dynamic increase in the deployment of the cut-to-length method [21] using of harvesters and forwarders has been observed in recent years. Leading this trend is Estonia, where as much as $95 \%$ of final felling and $80 \%$ of thinning are carried out with machine technology [22]. Although motor-manual technology prevails in logging in Poland [23], the use of specialised machines is dynamically increasing, both in technological wood harvesting (harvesters) and transport (forwarders) processes.

Wood harvesting in Poland exhibits dynamic growth in the mechanisation of wood harvesting processes (harvesters) as well as wood transportation (forwarders). Indeed, the number of the machines has dramatically increased in recent years. Mederski et al. [24] write that there were 530 harvesters in 2015, while a decade before, only 20 such machines were in operation. To move efficiently in the forest, these machines, and forwarders in particular, require wider strip roads than mini-forwarders or agricultural tractors with self-loading trailers, which are usually used in Poland. On the other hand, wider strip roads change the growth conditions of trees growing next to them to a greater extent [25].

The cutting of strip roads affects both the tree stand as a whole and the single trees growing directly along the roads (edge trees). The effect on the tree stand constitutes a reduction in its wood-production potential, which although clearly visible at the moment of cutting, loses its significance with the progress of time [26]. The influence on edge trees results from an influx of sunlight to the crowns and from their larger living space. This leads to the so-called edge effect in the form of a larger wood increment [27-31]. However, according to the scientific literature, this effect is not always present [32-34]. When a strip road is present, the living space of the edge trees is enlarged from the side of the strip road. It can be expected that this fact will not only result in increased tree growth but will also affect the shapes and structural traits of the individual trees, determining the quality of the future wood.

This research aimed to assess the effects of strip roads on the growth in diameter and on the pith eccentricity of trees growing along the strip roads. It was assumed that an increase in the living space of these trees would increase their growth in diameter, but that at the same time, it would cause some eccentricity in the stem pith, visible on the crosscut of the stems, resulting from the one-sided influence (from the strip road).

\section{Materials and Methods}

\subsection{Study Area}

The investigations were conducted in a 42-year-old pine tree stand (Pinus sylvestris L.) with single birches (Betula pendula L.), located in the south-eastern part of the Notecka Forest $\left(52^{\circ} 68^{\prime} 59^{\prime \prime} \mathrm{N}, 16^{\circ} 61^{\prime} 59^{\prime \prime} \mathrm{E}\right)$. The tree stand was growing on flat terrain on rusty podzolic soil, and the stand density was moderate. In the same tree stand, 10 years before, thinning had been performed according to the tree-length wood-harvesting method on one experimental plot, and according to the cut-to-length method on another one [21]. The wood was cut with a chainsaw and then skidded with an agricultural tractor Ursus C-360 (for the tree-length method) or forwarded with a Timberjack 1010 (for the cut-to-length method). The thinned tree stand was opened with a net of $2.5 \mathrm{~m}$ wide strip roads for the tractor $(2.5 \mathrm{~m}$ variant) and $3.5 \mathrm{~m}$ wide strip roads for the forwarder ( $3.5 \mathrm{~m}$ variant), cut every $30 \mathrm{~m}$. The mean diameter at breast height of the trees was $14.5 \mathrm{~cm}$ in the $3.5 \mathrm{~m}$ variant and $14.2 \mathrm{~cm}$ in the $2.5 \mathrm{~m}$ variant; the mean tree height was $14.8 \mathrm{~m}$ in both variants. 


\subsection{Experimental Design}

For each variant, four strip roads were selected, from which three distance zones were established: $0-1 \mathrm{~m}, 2-4 \mathrm{~m}$ and $8-10 \mathrm{~m}$ away from the strip road. The $0-1 \mathrm{~m}$ distance zone included the edge trees, while the 2-4 $\mathrm{m}$ distance zone was inspired by scientific literature indicating that the potential influence of strip roads reached up to approximately $3 \mathrm{~m}[28-30,35]$; the 8-10 $\mathrm{m}$ distance zone included trees inside the stand and represented the control. The trees in each of the distance zones were marked with different colours, followed by the DBH (Diameter and Breast Height) measurements, in two perpendicular directions: N-S and W-E.

Wood increment and pith eccentricity analysis was performed in each distance zone on 12 felled sample trees (4 strip road $\times 3$ trees). Altogether, in each of the two strip road width variants, 36 sample trees were felled ( 3 zone $\times 12$ trees). The three sample trees in each distance zone had been selected based on DBH measurements of all the trees in the zone. It was assumed that one sample tree should have the average breast height diameter value for the given distance zone, and the other two should have the average DBH value enlarged by the standard deviation and the average DBH value reduced by the standard deviation value, respectively. The heights of the sample trees were taken from the height curves derived from the height measurements of $20 \%$ of the trees in the respective zones.

After the sample trees were selected and marked, they were felled and divided into $2 \mathrm{~m}$ long sections. From the midpoints of the sections (from heights of 1, 3, 5, 7, 9, 11, 13 and $15 \mathrm{~m}$ ), discs were cut and stored for a short period to dry out. Before measurements were taken, the discs were polished and the N-S and W-E diameters were marked with lines (the $\mathrm{N}$ direction had been marked before felling). Then, on each marked radius, two zones of five rings of wood were marked, starting from the perimeter and moving towards the pith. The marked rings reflected two five-year-long increment periods after the cutting of the strip roads. The measurements of the ring widths and their distances from the pith were taken with an electronic calliper in the N-S and W-E directions. The readings were rounded off to $0.01 \mathrm{~mm}$.

The pith eccentricity $(x)$ was calculated according to the following formula:

$$
x=\sqrt{\left(\frac{D_{W E}}{2}-R_{W}\right)^{2}+\left(\frac{D_{N S}}{2}-R_{N}\right)^{2}}(\mathrm{~mm})
$$

where

$D_{W E}, D_{N S}$ - diameters in the WE and NS directions,

$R_{W}, R_{N}$-distances between the pith-off-centre and the disc edge in the $\mathrm{W}$ and $\mathrm{N}$ directions (Figure 1).

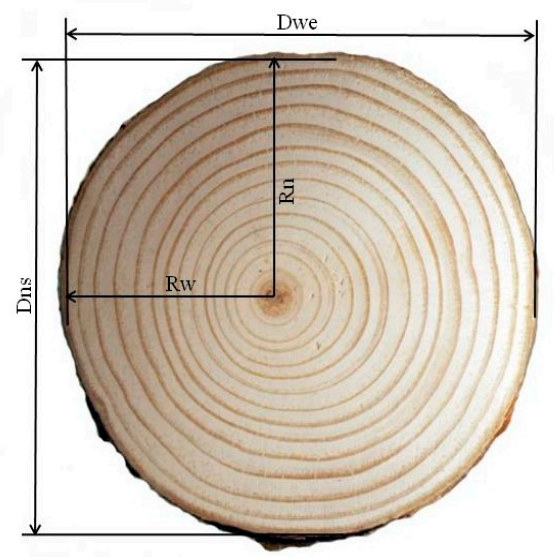

Figure 1. Measurement of the stem pith eccentricity. 
The relative eccentricity $\left(x_{w}\right)$ was calculated according to the following formula:

$$
x_{w}=\frac{x}{d}
$$

where

$d$-stem diameter at the eccentricity measurement $(\mathrm{mm})$.

Five-year growth values in thickness and the eccentricity of the stem pith were analysed in three height zones on the stem-the lower, middle and upper zones. The lower zone included 0-2 $\mathrm{m}$ and 2-4 m sections, the middle zone included $4-6 \mathrm{~m}$ and 6-8 $\mathrm{m}$ sections (in the case of six sections) and 4-6, 6-8 and 8-10 m sections (in the case of seven and eight sections) and the upper zone included 8-10 and 10-12 $\mathrm{m}$ sections (in the case of six sections), 10-12 and 12-14 m sections (in the case of seven sections) and 10-12, 12-14 and 14-16 m sections (in the case of eight sections; Figure 2a-c). In addition to the thickness increments and eccentricity, the frequency of stem pith displacements in the directions $\mathrm{N}-\mathrm{W}, \mathrm{S}-\mathrm{W}, \mathrm{N}-\mathrm{E}$ and S-E was also analysed, depending on the distance of the trees from the strip road and the height of the measurements (height zone).

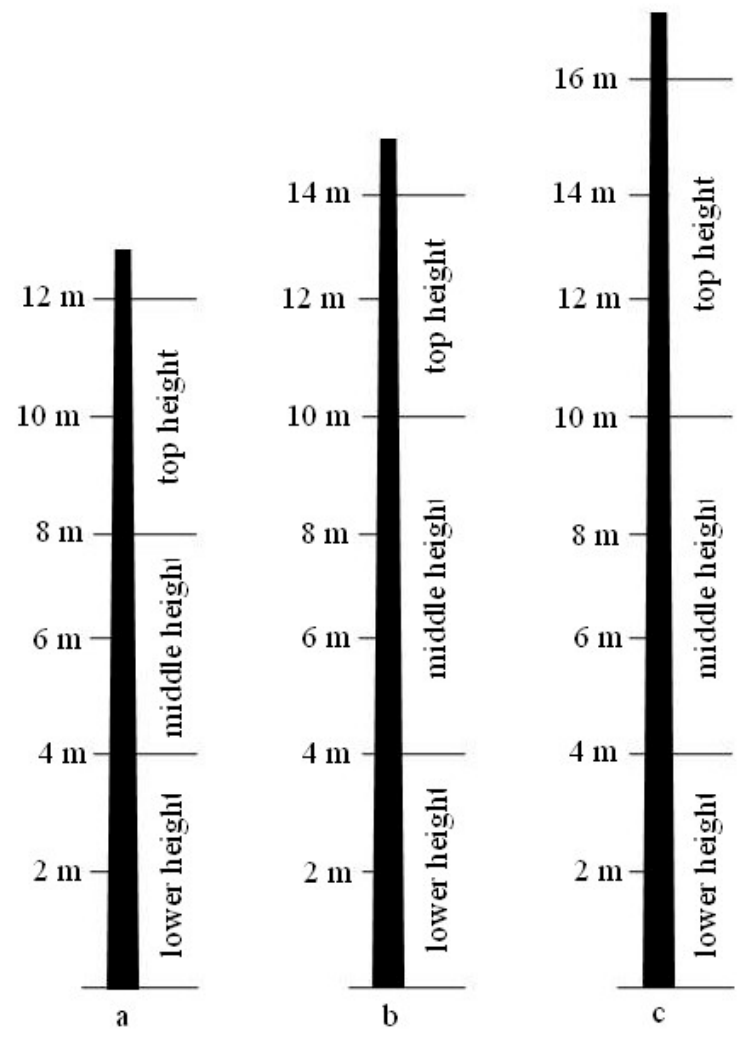

Figure 2. Height zones on the stem, depending on the number of $2 \mathrm{~m}$ long wood sections (a-6 sections, $\mathbf{b}-7$ sections, $\mathbf{c}-8$ sections).

\subsection{Statistical Analyses}

The statistical analysis comprised the assessment of the significance of differences in the increments and eccentricities between the distance zones. Depending on the distribution character of the variables, a one-way analysis of variance (ANOVA) or Kruskal-Wallis test was used. One-way analysis of variance (ANOVA) was chosen as the basic method of statistical analysis, because the distance between the tree and the strip road was considered to be the decisive independent variable. The compatibility of the distributions with the normal distribution was tested with a Shapiro-Wilk test. The relationship between the frequency of eccentricities in the N-W, S-W, N-E and S-E directions and the distance of the 
trees from the strip road or the measurement height was tested with the chi-square test. All statistical analyses were performed using the Statistica 12 software package (StatSoft Inc., Tulsa, OK, USA).

\section{Results}

\subsection{Growth in Diameter}

The research showed that both in the first as well as in the second five-year periods after cutting strip roads in the $3.5 \mathrm{~m}$ variant, the trees growing directly at the strip roads showed much larger growth in diameter than those growing at greater distances from the strip road (Table 1).

Table 1. Five-year growth in diameter ( $\mathrm{mm}$; mean values \pm standard error (SE)) at lower, middle and top height zones related to the distance from the strip road in the $3.5 \mathrm{~m}$ variant.

\begin{tabular}{ccccc}
\hline \multirow{2}{*}{$\begin{array}{c}\text { Five-Year } \\
\text { Growth Period }\end{array}$} & $\begin{array}{c}\text { Distance from } \\
\text { Strip Road }(\mathrm{m})\end{array}$ & Lower Height & Middle Height & Top Height \\
\cline { 3 - 5 } & $0-1$ & $17.7 \pm 1.2 \mathrm{a}$ & $18.9 \pm 1.3 \mathrm{a}$ & $27.6 \pm 1.6 \mathrm{a}$ \\
& $2-4$ & $14.4 \pm 0.9 \mathrm{ab}$ & $15.9 \pm 1.0 \mathrm{ab}$ & $26.7 \pm 1.5 \mathrm{a}$ \\
$\mathrm{I}$ & $8-10$ & $12.2 \pm 1.0 \mathrm{~b}$ & $13.9 \pm 1.0 \mathrm{~b}$ & $24.1 \pm 1.2 \mathrm{a}$ \\
\hline & $0-1$ & $14.3 \pm 1.2 \mathrm{a}$ & $15.2 \pm 1.0 \mathrm{a}$ & $25.1 \pm 1.7 \mathrm{a}$ \\
& $2-4$ & $11.4 \pm 0.9 \mathrm{a}$ & $12.1 \pm 0.7 \mathrm{~b}$ & $22.8 \pm 1.4 \mathrm{a}$ \\
II & $8-10$ & $11.5 \pm 1.3 \mathrm{a}$ & $12.2 \pm 0.9 \mathrm{ab}$ & $22.6 \pm 1.1 \mathrm{a}$ \\
\hline
\end{tabular}

Values with the same letter are not significantly different $(p<0.05)$. Different letters after values indicate significant differences by Duncan's or Tukey's test $(p<0.05)$.

The data presented in Table 1 indicate that increased growth in diameter in the first five-year period after cutting the strip roads was also observed for trees growing approximately $3 \mathrm{~m}$ away from the strip road. The growth of these trees was significantly greater than that of the trees from the 8-10 $\mathrm{m}$ distance zone, with the percentage differences decreasing with increasing height of the stem $(18 \%, 14 \%$ and $10 \%$ for the lower, middle and top height zones, respectively). This relationship was not observed in the second five-year growth period, for which the growth in diameter of the trees from the $2-4 \mathrm{~m}$ distance zone was, at each height, smaller than the growth observed in trees from the 8-10 $\mathrm{m}$ distance zone (Table 1).

Although the edge trees, both in the first and second growth periods, showed considerably greater growth in diameter, the differences were statistically significant only for the lower and middle height zones (for the second incremental period, only for the middle height zone; Table 1). The first five-year increment in the thickness of edge trees, both in the lower-height and middle-height zones, was significantly greater than the increment of trees in the control area $(8-10 \mathrm{~m})$, while the second five-year increment was significantly greater than the increment of trees at the $2-4 \mathrm{~m}$ distance zone only in the middle-height zone.

Furthermore, in the $2.5 \mathrm{~m}$ variant, the edge trees showed the largest wood increment values both in the first as well as in the second five-year period (Table 2). The data presented in Table 2 indicate that the influence of the strip road in this variant barely extended outside the edge trees. Although the first five-year increment in the thickness of trees at the 2-4 m distance zone was greater than in the control area $(8-10 \mathrm{~m})$, the differences were much smaller than in the $3.5 \mathrm{~m}$ variant $(5.5 \%, 3.9 \%$ and $0.9 \%$ for the lower, middle and top height zones), while the second five-year increment in the thickness of these trees was-regardless of height-smaller in the control area. 
Table 2. Five-year growth in diameter (mm; mean values \pm SE) at lower, middle and top height zones related to the distance from the strip road in the $2.5 \mathrm{~m}$ variant.

\begin{tabular}{ccccc}
\hline \multirow{2}{*}{$\begin{array}{c}\text { Five-Year } \\
\text { Growth Period }\end{array}$} & $\begin{array}{c}\text { Distance from } \\
\text { Strip Road (m) }\end{array}$ & Lower Height & Middle Height & Top Height \\
\cline { 3 - 5 } & $0-1$ & $13.8 \pm 0.8 \mathrm{a}$ & $16.9 \pm 1.0 \mathrm{a}$ & $27.5 \pm 1.7 \mathrm{a}$ \\
& $2-4$ & $11.5 \pm 1.0 \mathrm{ab}$ & $13.3 \pm 1.1 \mathrm{bc}$ & $22.2 \pm 1.3 \mathrm{ab}$ \\
$\mathrm{I}$ & $8-10$ & $10.9 \pm 0.7 \mathrm{~b}$ & $12.8 \pm 0.9 \mathrm{c}$ & $22.0 \pm 1.3 \mathrm{~b}$ \\
& $0-1$ & $11.3 \pm 0.9 \mathrm{a}$ & $13.5 \pm 0.9 \mathrm{a}$ & $24.3 \pm 1.5 \mathrm{a}$ \\
& $2-4$ & $8.5 \pm 0.8 \mathrm{a}$ & $9.9 \pm 0.7 \mathrm{a}$ & $19.3 \pm 1.1 \mathrm{~b}$ \\
II & $8-10$ & $9.0 \pm 0.7 \mathrm{a}$ & $10.4 \pm 0.7 \mathrm{a}$ & $19.8 \pm 1.3 \mathrm{ab}$ \\
\hline
\end{tabular}

Values with the same letter are not significantly different $(p<0.05)$. Different letters after values indicate significant differences by Duncan's or Tukey's test $(p<0.05)$.

The statistical analysis of the growth in thickness in this variant for the first five-year period showed significant differences for all heights on the stem, while for the second five-year period, only for the top height zone (Table 2). The first five-year increment in the thickness of the edge trees in the lower- and top-height zones was significantly greater than at the 8-10 $\mathrm{m}$ distance zone, while in the middle height zone, it was greater than at the 2-4 $\mathrm{m}$ and 8-10 $\mathrm{m}$ distance zones. The second five-year increment in the thickness of the edge trees in the top height zone was significantly larger than at the $2-4 \mathrm{~m}$ distance zone (Table 2).

The average five-year growth values in thickness from all heights (Table 3) showed similar regularities to the results for the respective height zones.

Table 3. Five-year growth in diameter $(\mathrm{mm})$ of the whole tree (Mean values $\pm \mathrm{SE}$ ) related to the distance from the strip road.

\begin{tabular}{cccc}
\hline \multirow{2}{*}{$\begin{array}{c}\text { Five-Year Growth } \\
\text { Period }\end{array}$} & $\begin{array}{c}\text { Distance from } \\
\text { Strip Road (m) }\end{array}$ & $\mathbf{3 . 5} \mathbf{~}$ & $\mathbf{2 . 5} \mathbf{~ m}$ \\
\cline { 3 - 4 } & $0-1$ & $21.0 \pm 0.9 \mathrm{a}$ & $18.1 \pm 0.9 \mathrm{a}$ \\
& $2-4$ & $18.9 \pm 0.9 \mathrm{ab}$ & $15.3 \pm 0.8 \mathrm{ab}$ \\
$\mathrm{I}$ & $8-10$ & $16.1 \pm 0.8 \mathrm{~b}$ & $14.8 \pm 0.8 \mathrm{~b}$ \\
\hline \multirow{2}{*}{$\mathrm{II}$} & $0-1$ & $17.3 \pm 0.9 \mathrm{a}$ & $14.8 \pm 0.8 \mathrm{a}$ \\
& $2-4$ & $14.8 \pm 0.8 \mathrm{a}$ & $11.6 \pm 0.7 \mathrm{~b}$ \\
& $8-10$ & $14.4 \pm 0.8 \mathrm{a}$ & $12.1 \pm 0.7 \mathrm{~b}$ \\
\hline
\end{tabular}

Values with the same letter are not significantly different $(p<0.05)$. Different letters after values indicate significant differences by Duncan's test $(p<0.05)$.

The growth of the edge trees both in the first and in the second five-year periods, regardless of the strip road width, was much greater than the growth values of the other trees. In the $3.5 \mathrm{~m}$ variant, for the first growth period, a considerable difference between the growth of the trees $3 \mathrm{~m}$ from the strip road and the trees from the control area was found. In the $2.5 \mathrm{~m}$ variant, this difference was much smaller: $0.7 \mathrm{~mm}$ (while it was $2.7 \mathrm{~mm}$ for the wider strip roads).

In both variants, significant statistical differences between the growth values in thickness were found for trees from different distance zones in the first period. The growth of the edge trees in this period was significantly larger than that of the trees from the 8-10 m distance zone. In the second analysed period, the thickness growth values did not show significant differences in the $3.5 \mathrm{~m}$ variant, whereas in the $2.5 \mathrm{~m}$ variant, thickness growth values for edge trees were significantly larger than those for the trees from the $2-4 \mathrm{~m}$ and 8-10 m distance zones. 


\subsection{Stem Pith Eccentricity}

Results of the pith eccentricity analysis showed that all the measured trees showed a shift of the pith from the geometrical centre of the stem (Table 4).

Table 4. Stem pith eccentricity ( $\mathrm{mm}$; mean values $\pm \mathrm{SE}$ ) related to the height on the tree and the distance from the strip road.

\begin{tabular}{ccccc}
\hline \multirow{2}{*}{ Variant } & \multirow{2}{*}{$\begin{array}{c}\text { Distance from } \\
\text { Strip Road }(\mathbf{m})\end{array}$} & Lower Height & Middle Height & Top Height \\
\cline { 3 - 5 } & $0-1$ & $8.4 \pm 0.7 \mathrm{a}$ & $5.2 \pm 0.5 \mathrm{a}$ & $2.6 \pm 0.3 \mathrm{a}$ \\
& $2-4$ & $7.3 \pm 0.6 \mathrm{a}$ & $4.8 \pm 0.4 \mathrm{a}$ & $2.9 \pm 0.3 \mathrm{a}$ \\
$3.5 \mathrm{~m}$ & $8-10$ & $8.5 \pm 0.9 \mathrm{a}$ & $4.7 \pm 0.4 \mathrm{a}$ & $2.1 \pm 0.2 \mathrm{a}$ \\
& $0-1$ & $8.7 \pm 1.0 \mathrm{a}$ & $5.5 \pm 0.5 \mathrm{a}$ & $2.4 \pm 0.3 \mathrm{a}$ \\
& $2-4$ & $7.0 \pm 0.7 \mathrm{a}$ & $4.7 \pm 0.5 \mathrm{a}$ & $1.7 \pm 0.2 \mathrm{a}$ \\
$2.5 \mathrm{~m}$ & $8-10$ & $8.3 \pm 1.2 \mathrm{a}$ & $5.5 \pm 0.6 \mathrm{a}$ & $2.3 \pm 0.2 \mathrm{a}$ \\
\hline
\end{tabular}

The pith shift values measured on trees from different zones did not show any considerable differences. The maximum values, at different measuring heights, were found on the edge trees, as well on trees from the $2-4 \mathrm{~m}$ and $8-10 \mathrm{~m}$ distance zones in the $3.5 \mathrm{~m}$ variant, and on trees from the $0-1 \mathrm{~m}$ and $8-10 \mathrm{~m}$ distance zones in the $2.5 \mathrm{~m}$ variant. The statistical analysis showed no significant differences in absolute or relative pith eccentricities between distance zones.

In accordance with best methodological practice," this study analysed the relation between the frequency of pith eccentricity in different geographical directions and the distance of trees from the strip road as well as the height of the measurement. Due to the rarity of cases of pith shift in the N-E and S-E directions (Figures 3-5), the analysis focused on shifts in the N-W and S-W directions only.

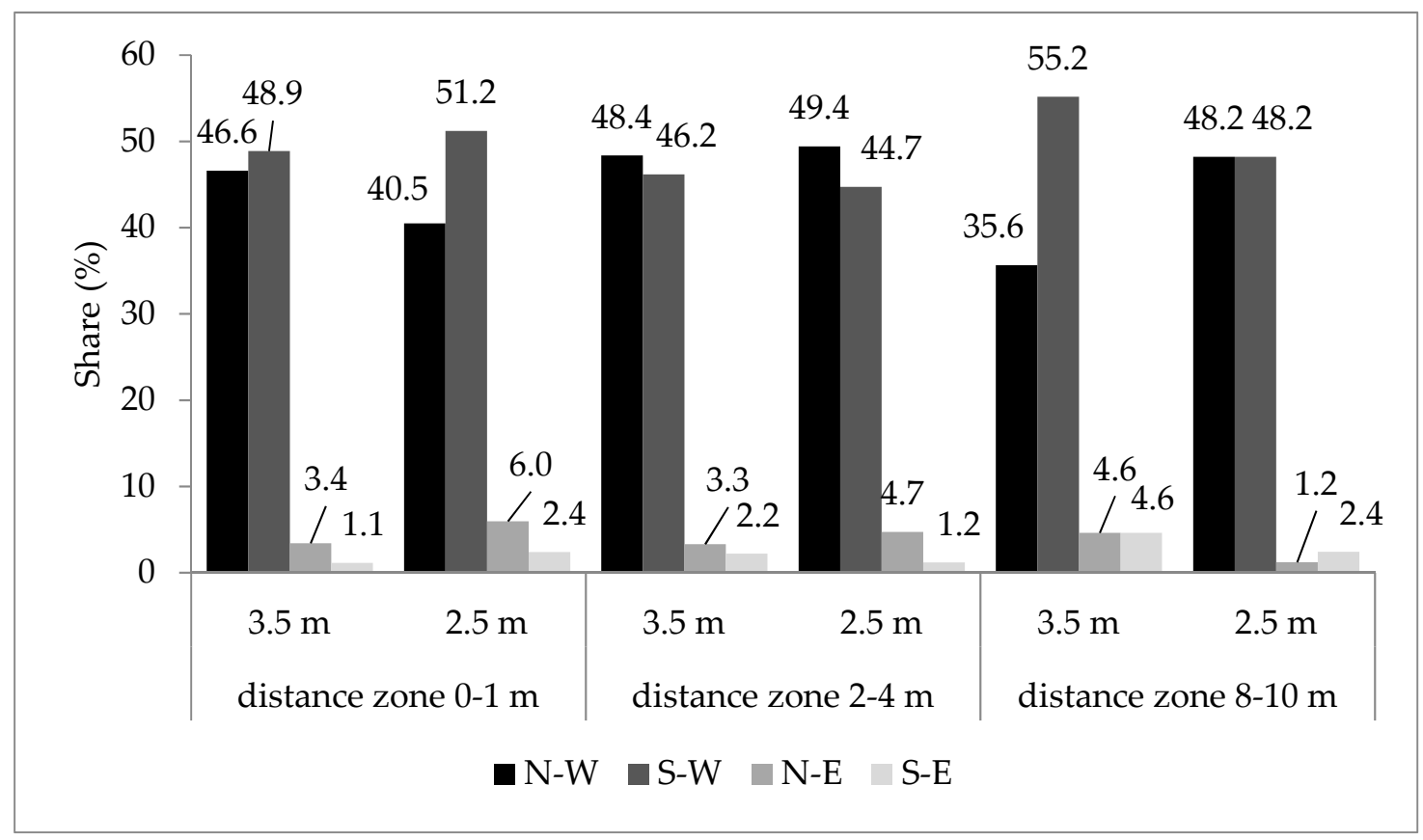

Figure 3. Stem pith shifts beside wider $(3.5 \mathrm{~m})$ and narrower $(2.5 \mathrm{~m})$ strip roads, showing movement in different directions (N-W, S-W, N-E, S-E) depending on the distance of trees from the strip road. 


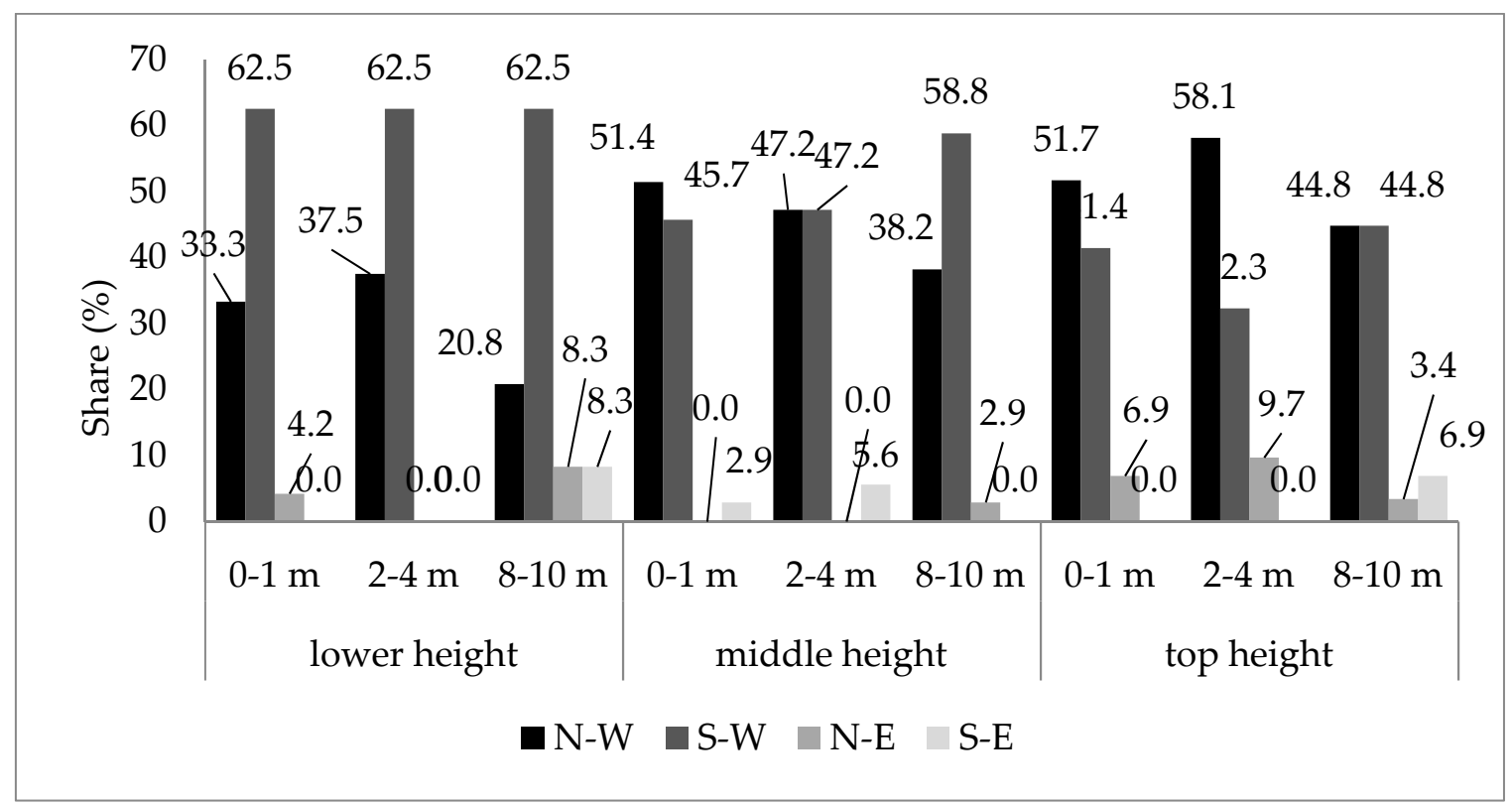

Figure 4. Stem pith shifts related to height of measurement in the $3.5 \mathrm{~m}$ variant, in different $(0-1,2-4,8-10 \mathrm{~m})$ distance zones from the strip road.

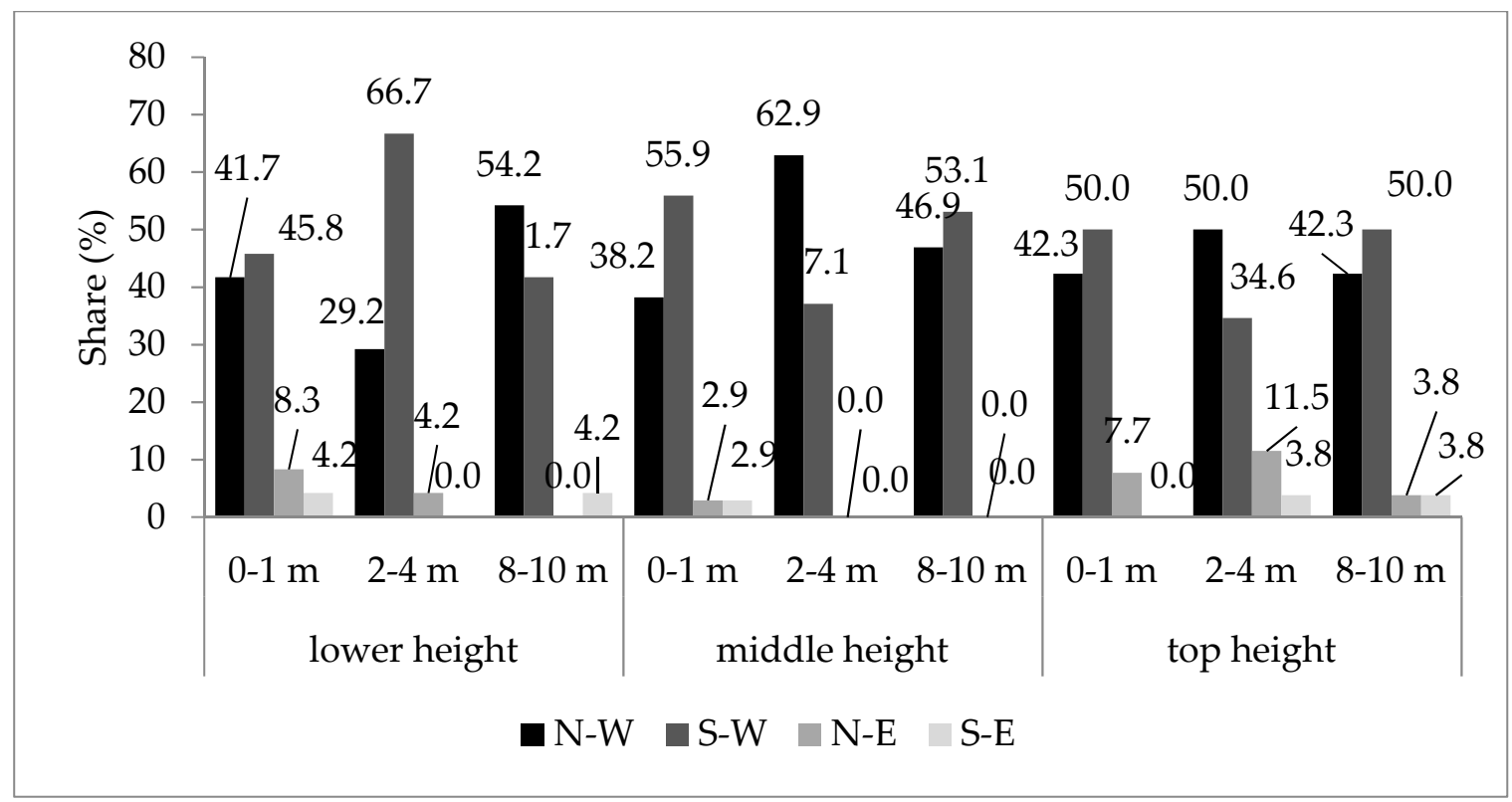

Figure 5. Stem pith shifts related to height of measurement in the $2.5 \mathrm{~m}$ variant in different $(0-1,2-4,8-10 \mathrm{~m})$ distance zones from the strip road.

Both in the $3.5 \mathrm{~m}$ as well as in the $2.5 \mathrm{~m}$ variant, the pith in the edge trees was more often shifted to the S-W than in the N-W direction, while in the $2-4 \mathrm{~m}$ distance zone, the situation was the opposite. In the control area, the pith shifts were usually in the S-W direction in the $3.5 \mathrm{~m}$ variant, whereas in the $2.5 \mathrm{~m}$ variant, no differences were observed (Figure 3). The chi-square test did not show any statistically significant relationship between the direction of the pith shift and the distance from the strip road (Table 5). 
Table 5. Cross table (in brackets: \%) and chi-square results for eccentricity directions (S-W, N-W) and distance from the strip road.

\begin{tabular}{|c|c|c|c|c|}
\hline \multirow{2}{*}{ Direction } & \multicolumn{3}{|c|}{ Distance from Strip Road (m) } & \multirow{2}{*}{ Total } \\
\hline & 0-1 & $2-4$ & 8-10 & \\
\hline \multicolumn{5}{|c|}{$3.5 \mathrm{~m}$ variant $\left(\chi^{2}=2.60, \mathrm{df}=2, p=0.272\right)$} \\
\hline S-W & $43(51.19)$ & $42(48.84)$ & $38(55.07)$ & $123(51.46)$ \\
\hline $\mathrm{N}-\mathrm{W}$ & $41(48.81)$ & $44(51.16)$ & $31(44.93)$ & $116(48.54)$ \\
\hline Total & $84(100)$ & $86(100)$ & $69(100)$ & $239(100)$ \\
\hline \multicolumn{5}{|c|}{$2.5 \mathrm{~m}$ variant $\left(\chi^{2}=1.15, \mathrm{df}=2, p=0.5636\right)$} \\
\hline S-W & $43(55.84)$ & 38 (47.5) & $40(50)$ & 121 (51.05) \\
\hline $\mathrm{N}-\mathrm{W}$ & $34(44.16)$ & $42(52.5)$ & $40(50)$ & $116(48.95)$ \\
\hline Total & $77(100)$ & $80(100)$ & $80(100)$ & $237(100)$ \\
\hline
\end{tabular}

The assessment of the relationship between the direction of the pith shift and the height at which the shift was measured showed that in the $3.5 \mathrm{~m}$ variant, regardless of the distance from the strip road, the piths were shifted in the $\mathrm{S}-\mathrm{W}$ direction in the lower parts of the trees. In the middle section of the stems, in trees growing close to the strip road, the piths were shifted more in the N-W direction than to the S-W. In the 2-4 m distance zone area, no differences between these directions were observed, while in the control area, pith shifts in the S-W direction prevailed. In the upper parts of the trees, at the 0-1 and 2-4 m distance zones, pith shifts in the $\mathrm{N}-\mathrm{W}$ direction dominated, and in the control area, the pith shifts were equally distributed between the N-W and S-W directions (Figure 4).

In general, in the $2.5 \mathrm{~m}$ variant, the piths were shifted in the S-W direction. They were observed at the distances of $0-1$ and 2-4 $\mathrm{m}$ in the lower parts of the trees, and at distance zones of $0-1$ and $8-10 \mathrm{~m}$ in the middle and upper sections of the trees. The pith shifts in the N-W direction prevailed in the lower parts of the trees in the control area and the middle and upper sections of trees growing at the 2-4 m distance zone (Figure 5). A statistically significant relationship between the number of pith shifts in the N-W and S-W directions and the measuring heights was found for the 2-4 m distance zone in the $2.5 \mathrm{~m}$ variant (Table 6). Here, the piths were statistically significantly more often shifted in the $\mathrm{S}-\mathrm{W}$ direction in the lower parts of the trees than in the middle sections (Table 7). For the other two distance zones in this variant, as well as at all three distance zones in the $3.5 \mathrm{~m}$ variant, no statistically significant relationship was found between the height on the stem and pith shifts in any direction (Table 6).

Table 6. Chi-square test results between the eccentricity direction $(\mathrm{S}-\mathrm{W}, \mathrm{N}-\mathrm{W})$ and height on the stem (value in bold denotes statistical significance).

\begin{tabular}{|c|c|c|c|c|c|c|}
\hline \multirow{3}{*}{$\begin{array}{l}\text { Distance from } \\
\text { Strip Road (m) }\end{array}$} & \multicolumn{6}{|c|}{ Variant } \\
\hline & \multicolumn{3}{|c|}{$3.5 \mathrm{~m}$} & \multicolumn{3}{|c|}{$2.5 \mathrm{~m}$} \\
\hline & $x^{2}$ & df & $p$ & $x^{2}$ & df & $p$ \\
\hline $0-1$ & 2.54 & 2 & 0.2815 & 0.29 & 2 & 0.8644 \\
\hline $2-4$ & 3.74 & 2 & 0.1540 & 6.38 & 2 & 0.0412 \\
\hline $8-10$ & 2.96 & 2 & 0.2272 & 0.67 & 2 & 0.7152 \\
\hline
\end{tabular}

Table 7. Crosstable of frequency (in brackets: \%) in stem-pith eccentricity at 2-4 m distance zone for the $2.5 \mathrm{~m}$ variant $\left(\chi^{2}=5.84, \mathrm{df}=1, p=0.0157\right)$.

\begin{tabular}{cccc}
\hline \multirow{2}{*}{ Direction } & \multicolumn{3}{c}{ Height on Tree } \\
\cline { 2 - 4 } & Lower Height & Middle Height & Total \\
\hline S-W & $16(69.57)$ & $13(62.86)$ & $29(50)$ \\
N-W & $7(30.43)$ & $22(37.14)$ & $29(50)$ \\
Total & $23(100)$ & $35(100)$ & $58(100)$ \\
\hline
\end{tabular}


It was found that relative eccentricity decreased with its height on the stem, and this was particularly visible in the $2.5 \mathrm{~m}$ variant (Figure 6b). In the $3.5 \mathrm{~m}$ variant (Figure 6a) this phenomenon was not as distinct (lower relative eccentricity values at $9 \mathrm{~m}$ height, compared to $11 \mathrm{~m}$ and $13 \mathrm{~m}$ heights).
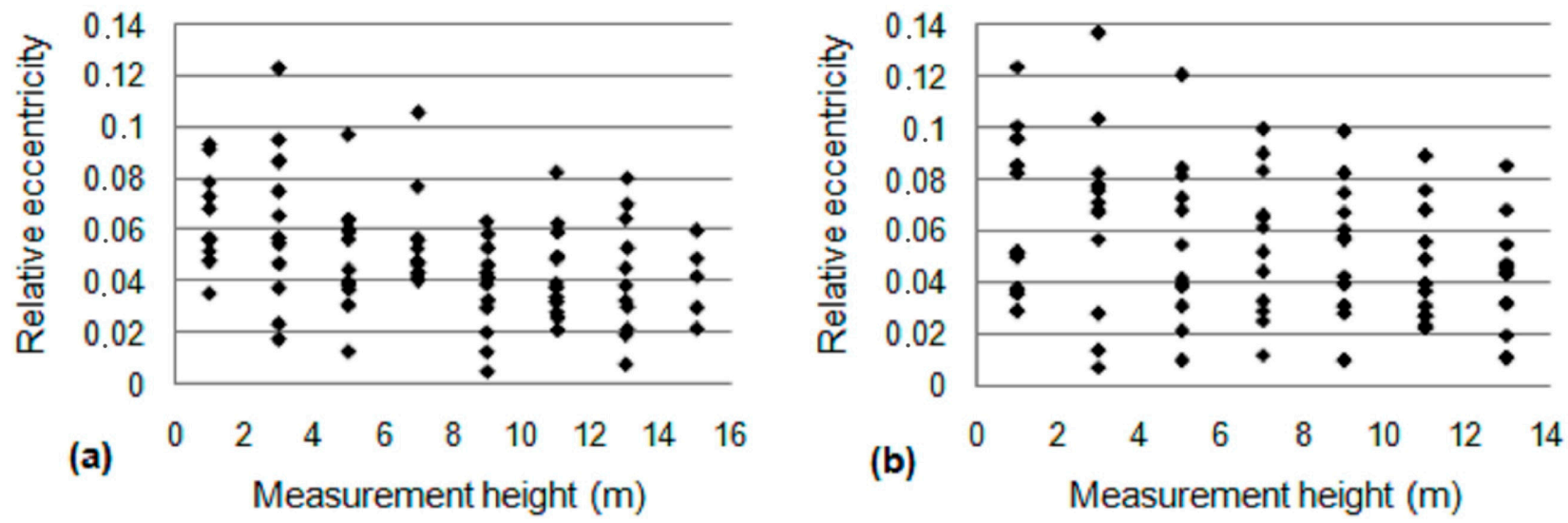

Figure 6. Distribution of eccentricity values in $3.5 \mathrm{~m} \mathrm{(a)} \mathrm{and} 2.5 \mathrm{~m}$ (b) variants.

\section{Discussion}

The results of the research showed larger wood increments on trees growing beside strip roads. Strip roads are characterised by a microclimate that is different from that in the interior of the forest, mainly due to greater heat and radiation absorption [36]. The intensified increment of these trees was primarily the effect of a change in lighting conditions on the strip roads. Studies have shown that the edge effect includes not only changes in lighting, but also temperature, humidity and wind flow streams [37,38]. An increased growth in trees along strip roads in Finland was reported by Isomäki and Niemistö [28], who analysed the influence of slightly wider strip roads (almost $4 \mathrm{~m}$ ) on the growth of spruce tree stands after the first thinning. The researchers noted an increased growth in the edge trees as quickly as the first year after the cutting of the strip roads, with its maximum reached five years after the cutting. In this paper, the yearly wood increment rings were not investigated; as such, it was difficult to find the point of maximum wood increment resulting from the influx of sunlight. Nevertheless, the wood increment in trees from the 2-4 m distance zone in the first five-year period in the $3.5 \mathrm{~m}$ variant, and the lack of this effect in the second period, indicated that the wood increment intensified in the first five years after cutting the strip roads. Slightly different results for spruce growing in Sweden were obtained by Eriksson [39], who analysed five-year wood increments on trees growing at strip roads $3.5 \mathrm{~m}$ and $5 \mathrm{~m}$ wide. The researcher also found that the trees bordering the strip road grew thicker, but the wood increment was more intensive in the second five-year-long period rather than in the first. This phenomenon was not found for trees growing farther away from the strip roads. These trees showed, as in the above-presented paper, the largest wood increment in the first five-year period. Research into wood increments in pine tree stands undergoing thinning at different intensities was conducted by Wallentin and Nilsson [35]. These researchers also found increased wood increment values in trees beside strip roads in both normally thinned and more intensively thinned stands. In Germany, an increase in wood increments in 27-43-year-old spruce trees growing beside strip roads was determined by Kremer and Matthies [40]. A 30\% reduction in spruce growth in the first five years in Sweden was found by Wästerlund (1983), [41]. Furthermore, Bredberg and Wästerlund [42] reported a 12\% reduction in growth. In Poland, an investigation in a 39-year-old spruce-stand five years after cutting $5 \mathrm{~m}$ wide strip roads, was reported by Bembenek et al. [34]. The researchers did not find any significant differences between trees directly by the strip roads and those inside the stand. Only a slightly increased wood increment reaction in edge trees was observed, 
but this occurred as late as five years after the cutting of the strip roads. Statistically significant lower wood increment values on edge trees in a fir plantation were reported by Yilamz et al. [43]. The theory of an increased wood increment in edge trees resulting from a more intensive influx of light was not proven by Suwała [44] in pine tree stands after late thinning. He reported that trees growing up to a distance of $5 \mathrm{~m}$ from the strip road showed lesser wood increments than trees growing farther away in the tree stand. The reason for such results can be presumed to be the lesser ability of pine tree crowns to expand at more advanced ages. In a paper by Finnish researchers Isomäki and Niemistö [28], the effect of an increased wood increment reached up to a distance of $3 \mathrm{~m}$ from the strip road. Similar results were reported by Mäkinen et al. [29] over a decade later. Furthermore, in the above-presented paper, the effect of strip roads in the first five-year period after cutting was found not only in edge trees but also in those growing in the $2-4 \mathrm{~m}$ distance zone, and it was more pronounced in the $3.5 \mathrm{~m}$ variant than in variant with narrower strip roads $(2.5 \mathrm{~m})$. This suggests a relationship between the widths of strip roads and the distances up to which they affect the trees, a relationship also observed by Eriksson [39].

When analysing the growth reaction of trees near strip roads, it should be remembered that although these trees have better access to sunlight, their roots grow in soil compressed by moving machines [45]. The opinions of researchers concerning the effect of the compressed soil are not conclusive [46-53]. The problem of the relationship between growth reactions in trees and the static loads caused by machines was studied by Matthies [54]. He found that decreased growth resulting from soil compaction is often reported by American and South African researchers who study the effects of machines causing static loads of over $100 \mathrm{kPa}$. Papers by European researchers often report positive growth reactions in trees growing at the edge of strip roads, but the loads of the machines usually do not exceed $100 \mathrm{kPa}$, often falling within the 35-70 kPa range. Matthies, based on the data collected, divided the static loads of the machines into three categories: up to $50 \mathrm{kPa}, 50-100 \mathrm{kPa}$ and over $100 \mathrm{kPa}$. The load from the second category, although causing distinctive changes in soil structure, did not cause definite negative growth reactions. The loads of the machines used in the research reported here were within this range, and the results confirm the observations made by Matthies.

The results of the stem pith eccentricity studies showed that this wood defect was present in all trees, and the shift parameter did not depend on the distance from the strip road. Similar results were reported by Bembenek et al. [34]. Pith eccentricity is an effect of the tree adaptation to mechanical stress. In a stem that is not subjected to mechanical forces, the tree rings are concentric. External forces affect the cambium tissue, which leads to pith eccentricity $[55,56]$. The reaction of conifers to external forces takes the form of increased wood growth on the compressed side [57,58]. Pith eccentricity is often accompanied by the compression of the wood [59-61]. In the course of this research, clear pith shifts in the N-W and S-W directions were observed. This phenomenon was true for all the trees and had no relationship with the distance of the trees from the strip road. The causal factor in this case was wind, which is considered the factor that affects trees to the strongest degree [62-64]. In Poland, with westerly winds dominating, coniferous trees show larger wood increments on their eastern sides [65] and the stem piths are shifted towards the west. This was also confirmed in the above-presented paper; in both the $2.5 \mathrm{~m}$ and the $3.5 \mathrm{~m}$ variants, the proportion of the pith shifts in the N-W and S-W directions for all the distance zones put together amounted to approximately $94 \%$. Similar values were found for particular distance zones, which proved that the strip roads had no effect on the stem pith position. Furthermore, the height at which the eccentricity was measured did not affect results in regard to pith shift to the N-W or S-W. Slightly different results were obtained by Bembenek et al. [34], who admittedly found this defect on all trees regardless of position in relation to the strip road, although pith shift towards the west was proven only for tree sections taken from directly under the crowns of trees bordering the strip roads. The research results presented in this paper found that the pith eccentricities decreased with the height at which they were measured on the trees. 
Similar results were observed by Mäkinen [66] as well as Kang and Lee [67]. Relationships between the pith eccentricity and the stem diameter for deciduous trees (alder, maple and oak) were reported by Fallah et al. [68]. In the case of trees bordering the strip road, a directed influx of sunlight occurs, which can lead to an asymmetrical growth increment [69] and a greater degree of pith eccentricity, especially in the tree crown zone. The results presented above did not confirm this phenomenon, although in the case of the edge trees in the $3.5 \mathrm{~m}$ variant, a slight increase in relative eccentricity at a height of $11 \mathrm{~m}$, related to measurements taken at $9 \mathrm{~m}$, was observed (Figure 6a). In the case of the $2.5 \mathrm{~m}$ variant, the decrease in relative eccentricity with increasing measuring height was more even (Figure $6 \mathrm{~b}$ ), which would suggest the strip road width affected the pith eccentricity in the crown sections of the trees and at the bases of the crowns. The width of the strip road was reported as the factor affecting differentiations in stem ovalities (while it was not reported as affecting the eccentricity, stem ovality usually accompanies stem pith eccentricity) by Karaszewski et al. [70].

\section{Conclusions}

This research showed a positive effect of strip roads in terms of increases in the diameters of edge trees, and showed no negative effect on eccentricity. These results can be used in discussions about strip roads, which often mention not only the wood volume losses caused by their cutting, but also their negative impact (as a result of canopy breaking) on the proper development of trees at the edge of the strip road and, consequently, on the quality of wood from these trees.

The trees growing at the edges of both the wider and the narrower strip roads showed a considerably larger wood increment in diameter than those growing deeper in the tree stand in both analysed periods. This increase was statistically significantly greater than the wood growth of the trees growing in the 8-10 m distance zone, and in the case of the narrower strip roads in the second analysed five-year period, it was also greater than the growth in the trees at a distance of 2-4 m.

The effect of the wider strip roads was observed on trees growing at a distance of approximately $3 \mathrm{~m}$ from the strip road. The wood growth in diameter in these trees in the first five-year period after the cutting of the strip roads was considerably greater than in the trees in the control area. In the case of the narrower strip roads, the difference was much smaller. This phenomenon did not occur in the second five-year period. This increased growth in diameter in trees may, to a certain extent, compensate for volume losses caused by the cutting of strip roads.

There were no differences in the values of the eccentricities in the stem piths caused by the distances between the trees and the strip roads, which proves the lack of impact of strip roads on the occurrence of this defect in wood structure. There was also no statistically significant relationship between the distances of the trees from the strip road and the heights on the stem and the frequency of stem pith displacements in certain directions (with one exception, which concerned the height on the stem at the 2-4 m distance zone in the $2.5 \mathrm{~m}$ variant).

Supplementary Materials: The following are available online at https:/ /www.mdpi.com/article/10 $.3390 / \mathrm{f} 12101414 / \mathrm{s} 1$, Ryc. 5. Stem pith shifts related to the height of measurement in the $2.5 \mathrm{~m}$ variant at different $(0-1,2-4,8-10 \mathrm{~m})$ distances from the strip road.

Author Contributions: Conceptualisation, W.S.; methodology, W.S. and K.J.; writing-original draft preparation, W.S. and K.J.; writing—review and editing, W.S., K.J. and J.J.; formal analysis, J.J. All authors have read and agreed to the published version of the manuscript.

Funding: The publication is co-financed within the framework of the Polish Ministry of Science and Higher Education's program: "Regional Initiative Excellence" in the years 2019-2022 (No. 005/RID/2018/19).

Institutional Review Board Statement: Not applicable. 
Informed Consent Statement: Not applicable.

Data Availability Statement: The data is available as Supplementary Materials to the article.

Conflicts of Interest: The authors declare no conflict of interest.

\section{References}

1. Wiersum, K.F. 200 years of sustainability in forestry: Lessons from history. Environ. Manag. 1995, 19, 321-329. [CrossRef]

2. Hahn, W.A.; Knoke, T. Sustainable development and sustainable forestry: Analogies, differences, and the role of flexibility. Eur. J. For. Res. 2010, 129, 787-801. [CrossRef]

3. Sandström, C.; Lindkvist, A.; Öhman, K.; Nordström, E.-M. Governing competing demands for forest resources in Sweden. Forests 2011, 2, 218-242. [CrossRef]

4. Bartczak, A.; Lindhjem, H.; Ståle, N.; Zandersen, M.; Zylicz, T. Valuing forest recreation on the national level in a transition economy: The case of Poland. For. Policy Econ. 2008, 10, 467-472. [CrossRef]

5. Grilli, G.; Paletto, A.; De Meo, I. Economic valuation of forest recreation in an alpine valley. Balt. For. 2014, 20, 167-175.

6. Elbakidze, M.; Andersson, K.; Angelstam, P.; Armstrong, G.W.; Axelsson, R.; Doyon, F.; Hermansson, M.; Jacobsson, J.; Pautov, Y. Sustained yield forestry in Sweden and Russia: How does it correspond to sustainable forest management policy? Ambio 2013, 42, 160-173. [CrossRef] [PubMed]

7. Paschalis, P. Użytkowanie lasu wielofunkcyjnego. Sylwan 1996, 140, 5-11.

8. Bort, U.; Mahler, G.U.; Pfeil, C. Mechanisierte holzernte. Forsttech. Inf. 1993, 11, 121-124.

9. Sauter, U.H.; Busmann, C. Bestandesschäden bei der durchforstung von fichtenbeständen mit kranvollerntern unter berücksichtigung unterschiedlicher rückegassenabstände. Forsttech. Inf. 1994, 12, 137-141.

10. Han, H.-S.; Kellogg, L.D. Damage characteristics in young douglas-fir stands from commercial thinning with four timber harvesting systems. West. J. Appl. For. 2000, 15, 27-33. [CrossRef]

11. Košir, B. Damage to young forest due to harvesting in shelterwood systems. Croat. J. For. Eng. 2008, 29, 141-153.

12. von Wilpert, K.; Schäffer, J. Ecological effects of soil compaction and initial recovery dynamics: A preliminary study. Eur. J. For. Res. 2006, 125, 129-138. [CrossRef]

13. Ampoorter, E.; Van Nevel, L.; De Vos, B.; Hermy, M.; Verheyen, K. Assessing the effects of initial soil characteristics, machine mass and traffic intensity on forest soil compaction. For. Ecol. Manag. 2010, 260, 1664-1676. [CrossRef]

14. Solgi, A.; Naghdi, R.; Tsioras, P.A.; Nikooy, M. Soil compaction and porosity changes caused during the operation of timberjack 450C skidder in northern Iran. Croat. J. For. Eng. 2015, 36, 217-225.

15. Matangaran, J.R.; Kobayashi, H. The effect of tractor logging on forest soil compaction and growth of Shorea selanica seedlings in Indonesia. J. For. Res. 1999, 4, 13-15. [CrossRef]

16. Eliasson, L.; Wästerlund, I. Effects of slash reinforcement of strip roads on rutting and soil compaction on a moist fine-grained soil. For. Ecol. Manag. 2007, 252, 118-123. [CrossRef]

17. Labelle, E.R.; Jaeger, D. Quantifying the use of brush mats in reducing forwarder peak loads and surface contact pressures. Croat. J. For. Eng. 2012, 33, 249-274.

18. Siren, M.; Ala-Ilomäki, J.; Mäkinen, H.; Lamminen, S.; Mikkola, T. Harvesting damage caused by thinning of Norway spruce in unfrozen soil. Int. J. For. Eng. 2013, 24, 60-75. [CrossRef]

19. Borchert, H.; Huber, C.; Göttlein, A.; Kremer, J. Nutrient concentration on skid trails under brush-mats-Is a redistribution of nutrients possible? Croat. J. For. Eng. 2015, 36, 243-252.

20. Jiroušek, R.; Klvač, R.; Skoupỳ, A. Productivity and costs of the mechanized cut-to-length wood harvesting system in clear-felling operations. J. For. Sci. 2007, 53, 476-482. [CrossRef]

21. Pulkki, R.E. Glossary of Forest Harvesting Terminology. 2004. Available online: http://flash.lakeheadu.ca/ \{\}repulkki/REP_ terminology.pdf (accessed on 22 May 2017).

22. Moskalik, T.; Borz, S.A.; Dvořák, J.; Ferencik, M.; Glushkov, S.; Muiste, P.; Lazdin̄̌s, A.; Styranivsky, O. Timber harvesting methods in eastern european countries: A review. Croat. J. For. Eng. 2017, 38, 231-241.

23. Bodył, M. Rozmiar pozyskania maszynowego w polsce. Drwal. Pismo Przedsiębiorców Leśnych 2019, 3, 5-9.

24. Mederski, P.S.; Karaszewski, Z.; Rosińska, M.; Bembenek, M. Dynamics of harvester fleet change in poland and factors determining machine occurrence. Sylwan 2016, 160, 795-804.

25. Giefing, D.F.; Karaszewski, Z.; Ziemski, Z. The effect of strip roads established during late cleanings on the selected parameters of trees. Sylwan 2003, 3, 11-18.

26. Dušek, D.; Slodičák, M.; Novák, J.; Kacalek, D. Influence of skid rack width on spruce stand production. Zprávy Lesn. Výzkumu 2015, 60, 171-176.

27. Niemistö, P. A simulation method for estimating growth losses caused by strip roads. Scand. J. For. Res. 1989, 4, 203-214. [CrossRef]

28. Isomäki, A.; Niemistö, P. Effect of strip roads on the growth and yield of young spruce stands in southern finland. Folia For. 1990, $756,36$.

29. Mäkinen, H.; Isomäki, A.; Hongisto, T. Effect of half-systematic and systematic thinning on the increment of Scots pine and Norway spruce in Finland. Forestry 2005, 79, 103-121. [CrossRef] 
30. Horak, J.; Novák, J. Effect of stand segmentation on growth and development of Norway spruce stands. J. For. Sci. 2009, 55, 323-329. [CrossRef]

31. Kuliešis, A.; Aleinikovas, M.; Linkevičius, E.; Kuliešis, A.A.; Saladis, J.; Škèma, M.; Šilinskas, B.; Beniušienè, L. The impact of strip roads on the productivity of spruce plantations. Forests 2018, 9, 640. [CrossRef]

32. Laurow, Z. Szlaki technologiczne w procesie pozyskiwania drewna. Część II. Szlak a środowisko. Przegląd Tech. Rol. Leś. 1996, 6, 23-25.

33. Jansson, K.-J.; Wästerlund, I. Effect of traffic by lightweight forest machinery on the growth of young picea abies trees. Scand. J. For. Res. 1999, 14, 581-588. [CrossRef]

34. Bembenek, M.; Giefing, D.F.; Karaszewski, Z.; Lacka, A.; Mederski, P.S. Strip road impact on selected wood defects of Norway spruce (Picea abies (L.) H. Karst). Drewno 2013, 190, 63-76.

35. Wallentin, C.; Nilsson, U. Initial effect of thinning on stand gross stem-volume production in a 33-year-old Norway spruce (Picea abies (L.) Karst.) stand in Southern Sweden. Scand. J. For. Res. 2011, 26, 21-35. [CrossRef]

36. Forman, R.T.T.; Sperling, D.; Bissonette, J.A.; Clevenger, A.P.; Cutshall, C.D.; Dale, V.H.; Fahrig, L.; France, R.; Goldman, C.R.; Heanue, K.; et al. Road Ecology: Science and Solutions; Island Press: Washington, DC, USA, 2002.

37. Delgado J., D.; Arroyo N., L.; Arévalo, J.; Fernandez-Palacios J., M. Edge effects of roads on temperature, light, canopy cover, and canopy height in laurel and pine forests (Tenerife, Canary Islands). Landsc. Urban Plan. 2007, 81, 328-340. [CrossRef]

38. Pohlman, C.L.; Turton, S.M.; Goosem, M. Temporal variation in microclimatic edge effects near powerlines, highways and streams in Australian tropical rainforest. Agric. Meteorol. 2009, 149, 84-95. [CrossRef]

39. Eriksson, H. New results from plot no. 5 at sperlingsholm estate in southwestern Sweden in the European Stemnumber experiment in picea abies. Scand. J. For. Res. 1987, 2, 85-98. [CrossRef]

40. Kremer, J.; Matthies, D. Auswirkungen der befahrung auf das wachstum der forstlichen vegetation. AFZ Der Wald 1997, 52, 474-477.

41. Wästerlund, I. Strength components in the forest floor restricting maximum tolerable machine forces. J. Terramech. 1989, 26, 177-182. [CrossRef]

42. Bredberg, C.-J.; Wästerlund, I. Wurzel-und bodenschäden durch fahrzeuge. Forstwiss. Cent. 1983, 102, 86-98. [CrossRef]

43. Yilmaz, E.; Makineci, E.; Demir, M. Skid road effects on annual ring widths and diameter increment of fir (Abies bornmulleriana mattf.) trees. Transp. Res. Part D Transp. Environ. 2010, 15, 350-355. [CrossRef]

44. Suwała, M. Effect of soil disturbances by wood harvesting in late thinnings of pine stands on trees increment. Leś. Prace Bad. 2007, 3, 99-116.

45. Bejarano, M.D.; Villar, R.; Murillo, A.M.; Quero, J.L. Effects of soil compaction and light on growth of Quercus pyrenaica Willd. (Fagaceae) seedlings. Soil Tillage Res. 2010, 110, 108-114. [CrossRef]

46. Ares, A.; Terry, T.A.; Miller, R.E.; Anderson, H.W.; Flaming, B.L. Ground-based forest harvesting effects on soil physical properties and douglas-fir growth. Soil Sci. Soc. Am. J. 2005, 69, 1822-1832. [CrossRef]

47. Gebauer, R.; Martinkova, M. Effects of pressure on the root systems of Norway spruce plants (Picea abies [L.] Karst.). J. For. Sci. 2012, 51, 268-275. [CrossRef]

48. Fleming, R.L.; Powers, R.F.; Foster, N.W.; Kranabetter, J.M.; Scott, D.A.; Ponder, F., Jr.; Berch, S.; Chapman, W.K.; Kabzems, R.D.; Ludovici, K.H. Effects of organic matter removal, soil compaction, and vegetation control on 5-year seedling performance: A regional comparison of long-term soil productivity sites. Can. J. For. Res. 2006, 36, 529-550. [CrossRef]

49. Sanchez, F.G.; Scott, D.A.; Ludovici, K.H. Negligible effects of severe organic matter removal and soil compaction on loblolly pine growth over 10 years. For. Ecol. Manag. 2006, 227, 145-154. [CrossRef]

50. Tan, X.; Curran, M.; Chang, S.; Maynard, D. Early growth responses of lodgepole pine and douglas-fir to soil compaction, organic matter removal, and rehabilitation treatments in southeastern British Columbia. For. Sci. 2009, 55, $210-220$.

51. Ampoorter, E.; De Frenne, P.; Hermy, M.; Verheyen, K. Effects of soil compaction on growth and survival of tree saplings: A meta-analysis. Basic Appl. Ecol. 2011, 12, 394-402. [CrossRef]

52. Hattori, D.; Kenzo, T.; Irino, K.O.; Kendawang, J.J.; Ninomiya, I.; Sakurai, K. Effects of soil compaction on the growth and mortality of planted dipterocarp seedlings in a logged-over tropical rainforest in Sarawak, Malaysia. For. Ecol. Manag. 2013, 310, 770-776. [CrossRef]

53. Naghdi, R.; Solgi, A.; Labelle, E.R.; Zenner, E.K. Influence of ground-based skidding on physical and chemical properties of forest soils and their effects on maple seedling growth. Eur. J. For. Res. 2016, 135, 949-962. [CrossRef]

54. Matthies, D. Maschinelle holzernte und ihre auswirkungen auf unsere bestände. AFZ Der Wald 1997, 9, $471-473$.

55. Kojs, P.; Malik, I.; Wistuba, M.; Stopka, R.; Trabka, K. Mechanizmy wzrostu ekscentrycznego i formowania się drewna reakcyjnego w kontekście badań dendrogeomorfologicznych - wprowadzenie do nowej hipotezy. Stud. Mater. Cent. Edukac. Przyr.-Leś. 2012, $14,147-156$.

56. Tomczak, A.; Jelonek, T.; Pazdrowski, W. Pine (Pinus Sylvestris L.) trunk irregularity due to exposure to wind. For. Lett. 2012, 103, 41-46.

57. Tulik, M.; Jura-Morawiec, J. Reaction wood and tree crown architecture. Sylwan 2011, 155, 808-815.

58. Wistuba, M.; Papciak, T.; Malik, I.; Barnas, A.; Polowy, M.; Pilorz, W. Wzrost dekoncentryczny świerka pospolitego jako efekt oddziaływania dominującego kierunku wiatru (przykład z Hrubeégo Jesenika, Sudety Wschodnie). Stud. Mater. Cent. Edukac. Przyr.-Leś. 2014, 16, 63-73. 
59. Warensjö, M.; Rune, G. Stem straightness and compression wood in a 22-year-old stand of container-grown scots pine trees. Silva Fenn. 2004, 38, 143-153. [CrossRef]

60. Ren, H.; Wu, Y.; Zhu, X.-M. The quadratic B-spline curve fitting for the shape of log cross sections. J. For. Res. 2006, 17, 150-152. [CrossRef]

61. Šilhán, K. How different are the results acquired from mathematical and subjective methods in dendrogeomorphology? Insights Landslide Movements. Geomorphology 2016, 253, 189-198.

62. Ennos, A.R. Wind as an ecological factor. Trends Ecol. Evol. 1997, 12, 108-111. [CrossRef]

63. Duncker, P.; Spiecker, H. Compression wood formation and pith eccentricity in Picea abies L. depending on selected site-related factors: Detection of compression wood by its spectral properties in reflected light. TRACE-Tree rings archaeol. Climatol. Ecol. 2005, 3, 150-158.

64. Konôpka, B.; Zach, P.; Kulfan, J. Wind-An important ecological factor and destructive agent in forests. Lesn. Časopis-For. J. 2016, 62, 123-130. [CrossRef]

65. Rola, P.; Staniszewski, P.; Tomusiak, R.; Sekrecki, P.; Wysocka, N. Strukturalne właściwości drewna sosny zwyczajnej (Pinus sylvestris L.) w zależności od strony świata-wstępne wyniki badań. Stud. Mater. Cent. Edukac. Przyr.-Leś. 2014, 16, $28-33$.

66. Mäkinen, H. Effect of thinning and natural variation in bole roundness in Scots pine (Pinus Sylvestris L.). For. Ecol. Manag. 1998, 107, 231-239. [CrossRef]

67. Kang, W.; Lee, N.-H. Relationship between radial variations in shrinkage and drying defects of tree disks. J. Wood Sci. 2004, 50, 209-216. [CrossRef]

68. Fallah, A.; Riahifar, N.; Barari, K.; Parsakhoo, A. Investigating the out-of-roundness and pith-off-centre in stems of three broadleaved species in Hyrcanian forests. J. For. Sci. 2012, 58, 513-518. [CrossRef]

69. Liese, W.; Dadswell, H.E. Über den Einfluß der himmelsrichtung auf die länge von holzfasern und tracheiden. Holz Als Roh-Und Werkst. 1959, 17, 421-427. [CrossRef]

70. Karaszewski, Z.; Giefing, D.F.; Lacka, A.; Noskowiak, A. Ovality on trees adjacent to skid road. Ann. Wars. Univ. Life Sci.-SGGW For. Wood Technol. 2014, 86, 153-158. 